\title{
MARULIĆEV DISKURS O DJEVIČANSTVU U INSTITUCIJI I EVANDELISTARU
}

Izvorni znanstveni članak

Primljeno: 18. 1. 2019

Prihvaćeno: 4. 3. 2019

DOI: $10.15176 /$ vol56no206

UDK 821.163.42.09Marulić,M. $2-447.4$

\section{DUBRAVKA DULIBIĆ-PALJAR \\ Filozofski fakultet, Sveučilište Jurja Dobrile u Puli}

\begin{abstract}
Polazeći od suvremene feminističke književnohistoriografske i historiografske problematizacije djevičanstva, u članku se analizira Marulićev diskurs o djevičanstvu u moralnoteološkim spisima Institucija (1506) i Evanđelistar (1516). Analizom se navedenih djela nastoji razabrati i razumjeti način kojim se djevičanstvo kao složena i imanentno proturječna konstrukcija u Marulićevim tekstovima uspostavljala iznova obnavljajući svoja ishodišna utemeljenja, dok se naglasak postavlja na fenomen ženske asketske virilnosti, osobito karakterističan za rane tipove ženske svetosti koji prevladavaju u Instituciji.
\end{abstract}

Ključne riječi: Marko Marulić, Institucija, Evanđelistar, hagiografija, djevičanstvo

I.

Marulolozi obično ističu da je Marulićeva moralna teologija svojevrsna sinteza srednjovjekovne i humanističke etičko-moralne misli. Tako se naglašava da je humanistička usmjerenost na pojam "univerzalnoga čovjeka" (homo universalis) važna pretpostavka Marulićeve etičke upitanosti nad čovjekom i razvitkom ljudske osobe, ali i da na zahtjev epohe za obnovom (restauratio), koju prije svega shvaća kao "obnovu čovjeka i čovječnosti" (Banić-Pajnić 1992: 20), Marulić odgovara povratkom na iskonsko kršćanstvo gdje pronalazi idealni lik "novoga" čovjeka (isto).! Ta se "specifičnost Marulićeve koncepcije obnove" (isto) jasno očituje u njegovu apologetskome odbacivanju bilo kakve mogućnosti autonomne etičke utemeljenosti morala na onim filozofijskim klasičnim školama koje se kao reakcija na moralnu teologiju i praksu skolastičara sada iznova pojavljuju u "novome mišljenju". U njegovu su moralnoteološkome opusu stoga gusto razasute polemičke

${ }^{1}$ Vidi i detaljnu analizu kod Parlov 1996: 57-85; 2006: 289-305. 
invektive u kojima oštro razgraničava kršćanski od klasičnoga etičkog vida, dosljedno se protiveći tome da čovjek kao creatura Dei može biti mjerilom moralnoga zakona (usp. Šimundža 1985: 17-37; 1986: xvii-xxiv). Njegova je koncepcija ljudske osobe određena augustinovskom definicijom naslijeđene ljudske odgovornosti i u skladu s time on ne smatra da čovjek nije etičko biće, tj. da po naravi nije dobar, ali nužno pretpostavlja fundamentalnu činjenicu čovjekove etičke kolebljivosti (usp. Šimundža 1985: 17-37). Zato se Marulić i ne slaže s onim dijelom humanističkih kršćanskih moralista koji misao o obnovi izvorne čovjekove dobre naravi (instauratio conditiae nauture) uzdižu do najviše norme djelovanja (usp. Parlov 2006: 289-302), već se okreće asketskim životnim nazorima na tragu pokreta devotio moderna i izvornoga franjevaštva. Njegova se nauka o kreposti pritom ne oblikuje u smislu nekakva zaokružena teološkog sustava, već se koristi elementima različitih teologija. Prije svega, biblijskom i patrističkom teologijom, Anselmovom i Akvinčevom misli te kasnosrednjovjekovnom teologijom pobožnosti (Frömmigkeitstheologie) (usp. Parlov 1996: 57 i Posset 2014: 214-19). Ukratko, prožimajući različite teološke misli, a opet prije svega vođena humanističkim impulsom za obnovom čovjeka, Marulićeva se moralna teologija na toj osnovi uspostavlja kao praktična moralka čija će osnovna zadaća biti konkretna i praktična pouka koja pojedinca treba usmjeriti ispravnome kršćanskom životu (usp. Šimundža 1985: 13-37 i Banić-Pajnić 1992: 16-17). ${ }^{2}$

Te karakteristične crte Marulićeva moralnoga poučavanja na vidjelo osobito dolaze u moralnoteološkim priručnicima Instituciji (1506) i Evanđelistaru ${ }^{4}$ (1516). Institucija je strukturirana kao zbirka svetačkih života i pričica iz Biblije te crkvene povijesti koji su po uzoru na žanrovsku tradiciju i Marulićeva "uglednoga generičkog prethodnika”, rimskoga povjesničara Valerija Maksima, pripovjedno uobličeni u narativnu formu egzempla (usp. Novaković 1987: 9-31 i Zlatar 2001: 77-85). O tome u posvetnoj poslanici Jeronimu Ćipiku Marulić piše:

Što su neki učinili pišući povijest pogana, to je isto meni palo na um da pokušam čitajući najčešće životopise svetaca, naime, da odatle izvučem primjere kreposna života i da ih izložim na ugled onima koji i sami žude postati svetima; to pogotovu stoga što je od prirode tako dano da se na ljudsku dušu većma djeluje primjerom da bi se podvrgla težim naporima negoli upućivanjem i propisima. (Marulić 1986: 3)

Zadaća je spisa stoga bila omogućiti da se primjerima uzornoga prakticiranja vrline, a bez upuštanja u izlaganje, pa čak ni u sustavni pregled moralne doktrine, pojedince dovede do toga da preispitaju vlastita ponašanja i usvoje pravila kojih bi se valjalo pridržavati te tako oblikuju način života koji bi odgovarao smislu i vrijednostima kršćanskoga morala. U tom su smislu egzempli objedinjeni u određena tematski naslovljena poglavlja od kojih svako donosi izvjesne savjete i upute o moralnoj praksi (npr. O ljubavi prema Bogu, O gajenju

${ }^{2}$ O teološkim i filozofskim osnovama Marulićeva moralnoteološkoga rada vidi i Filipović 1983: 3-22; Bogišić 1985: 9-21; Tomasović 1999; Jozić 2009: 239-247; Parlov 2017: 42-56.

${ }^{3}$ Institucija = De institutione bene vivendi per exempla sanctorum. Citira se prema: Marulić 1986; 1987.

${ }^{4}$ Evanđelistar =Euangelistarium. Citira se prema: Marulić 1985. 
mira, O čuvanju ćudoredne čistoće, O šutljivosti i umjerenosti u govoru itd.), dok su i sama poglavlja grupirana u šest knjiga (prema šest radnih dana) koje predstavljaju etape na putu kršćana od spoznaje vjere do konačnoga spasenja (Tomasović 1986: xxxii). Osim toga, sveti su i biblijski primjeri unutar većine poglavlja strukturirani u dvije skupine, od kojih je prva bila namijenjena muškarcima, a druga ženama, a u duhu praktičnoga karaktera teksta i ta je raspodjela primjera po kategorijama objašnjena razlozima didaktičke i pragmatične prirode. Ukratko, zamisao je bila ponuditi moralne sadržaje oslobođene spekulacije i teorijskoga načina mišljenja koji je dotad bio uobičajen u skolastičkim moralnoteološkim traktatima i priručnicima; isto tako, usavršavanje $u$ moralnome ponašanju, duhovno razvijanje i prakticiranje vrline predstavlja se kao dio ćudorednoga života koji je također život svakog čovjeka: i duhovnika - klerika, redovnika te redovnica i svjetovnjaka, dakle svih onih koji, kao što čitamo u posveti, "i sami žude postati svetima". Za razliku od Institucije, Evanđelistar, taj veličinom drugi Marulićev moralnoteološki spis, bio je, prije svega, namijenjen duhovnicima. Podijeljen u sedam knjiga objedinjenih u tri veće cjeline, koje su sadržajno odgovarale nakani da se struktura teksta uskladi s naukom o trima osnovnim teološkim krepostima, Evanđelistar moralnu tematiku predstavlja s većom sklonošću spekulaciji i sistematskoj obradi ćudorednih pitanja negoli je to prisutno u Instituciji, mada se i dalje radi o pristupu poučavanju koje, prije svega, definira praktična svrha i zanimanje za pitanje konkretnih obveza i dužnosti (usp. Šimundža 1985: 13-40). S tih su sadržajnih i strukturalnih razloga ti Marulićevi moralnoteološki spisi često sagledavani kao cjelina (usp. Parlov 2006: 300), a ta će se praksa slijediti i ovdje.

Pa ipak, područje koje ću analizirati bit će tematski mnogo uže od opisanoga; ono će se oblikovati oko teme djevičanstva i osobitosti ženskih asketskih praksi. U najširemu će me smislu zanimati kako se u tim spisima izlaže kršćansko učenje o djevičanstvu, a ono što želim detaljnije ispitati Marulićeva je interpretacija ženskih svetačkih primjera. U tom ću se smislu prije svega usredotočiti na Instituciju i na razmatranje odabranih ženskih primjera: opsežnija bi analiza izlazila izvan okvira članka, a odabrani su primjeri zato tipske naravi.

Glavnina Marulićevih ženskih primjera dolazi iz dvaju tekstualnih izvora: srednjovjekovnoga ciklusa legendi o djevicama mučenicama i pustinjačkoga ciklusa. Marulić u tim egzemplima, upravo kao i u ostalima, obično preuzima tri događajno tipizirana odsječka hagiografskoga sadržaja: uvodnu svetačku biografiju, presudne događaje iz svetačkoga života te izuzetnu svetačku smrt, koje zaokružuje komentarom koji donosi objašnjenje (Zlatar 2001: 83). Komentari se, osim toga, pojavljuju na početku i/ili na kraju poglavlja ili neke manje zaokružene cjeline, a njihova je funkcija pojedince uputiti kako da na najbolji mogući način usvoje i primijene određenu pouku. Ograničivši se tako uglavnom na izbor iz tradicionalne literature, Marulić u Instituciji donosi primjere koji se u najširemu smislu odnose na dva najstarija tipa kršćanske svetosti: mučenički i monaško-asketski (usp. Parlov 2007: 65-84), dok se u nešto užemu smislu može govoriti o jednome tipu hagiografskoga djevičanstva i ženske askeze vopće. Taj je tip bio poznat po upečatljivoj ženskoj figuri koja se tradicionalno nazivala virago ili femina virilis, miles (žena koja se ponaša kao muškarac), a izvorno je bio oblikovan u ranokršćanskome kontekstu, iako tijekom čitavoga 
srednjeg vijeka, bez obzira na različite svoje varijacije i modifikacije, ostaje jednim od važnijih tipova hagiografskoga djevičanstva. ${ }^{5}$ Ono što će me zanimati u analizi nije, međutim, toliko sadržaj tih primjera niti kako se sadržajno odnose prema hagiografskim izvorima iz kojih su preuzeti, ${ }^{6}$ koliko su to autorovi komentari koji donose objašnjenja sadržaja svakoga pojedinog života, često uz dužu praktičnu uputu o najboljemu načinu prakticiranja određene vrline. Različite su vrline, međutim, isto tako često ilustrirane istim svetačkim likom i svetačkim životom, a s obzirom na to, koliko radi ekonomičnosti izlaganja, koliko opet radi mogućnosti produbljenije analize, usredotočit ću se na jedan svetački lik koji služi kao primjer različitim vrlinama, a najjasnije i ujedinjuje karakteristične crte onoga tipa djevičanstva koji prevladava u Instituciji.

Osim toga, kako je Marulićev pristup navedenim temama bio vrlo tradicionalan te $u$ skladu s cjelokupnim njegovim intelektualnim habitusom okrenut prema biblijskoj i patrističkoj teologiji, taj bi doktrinarni kontekst također valjalo razjasniti, barem u glavnim crtama. Pritom ću slijediti reinterpretaciju patrističke formulacije djevičanstva kakvu donosi suvremena feministička historiografija i književna historiografija okrenuta religijskom diskursu o djevičanstvu u ranokršćanskome i srednjovjekovnome razdoblju (tzv. feminist early Christianity studies i medieval virginity studies), ' dok se nekim doktrinarnim temama i pojmovima vraćam još i kasnije, detaljno ih obrazlažući u analizi konkretnih sadržaja Marulićevih spisa, gdje se služim istim interpretativnim strategijama. U skladu s time, cilj bi ove analize bio ponuditi nov pogled na objašnjenja i definicije djevičanstva (a u širemu smislu, seksualnosti, roda i spola) koje nalazimo u Marulićevim spisima, ${ }^{8}$ te iznijeti interpretaciju koja bi indirektno odražavala, u feministički usmjerenim čitanjima često prisutno, nastojanje da se analiza naglašeno ponaša i kao kritička praksa. ${ }^{9}$

${ }^{5}$ O glavnim karakteristikama toga tipa djevičanstva, kao i o relevantnoj literaturi, više govorim kasnije.

${ }^{6}$ Vidi o tome Zlatar 2001: 77-85.

7 Područje tzv. feminist early Christianity studies iznimno je razgranato te prije svega upućujem na nekoliko odabranih studija: Castelli 1986; 1991; 2001: 3-29; 2004: 1-33; 2017: 271-281; Clark 1983; 1984; 1986: 619-41; 1994: 155-184; 2001: 395-426; Elm 1994; Cloke 1995; Cox Miller 2005; Cobb 2008: 92-124; Chin i Schroeder 2017. Isto tako iz područja tzv. medieval virginity studies izdvajam sljedeće monografije i zbornike: Salisbury 1991; Evans i Johnson 1994; Newman 1995; Kelly i Leslie 1999; Kelly 2000; Salih 2001; Riches i Salih 2002; Bernau, Evans i Salih 2003; Mclnerney Burnett 2003; Allan, Santos i Spahr 2016.

${ }^{8}$ Pritom ističem da se temom djevičanstva kod Marulića s teološkoga stajališta bavi Parlov 2005: 293-312, dok je čitanje Marulićeve Institucije, koja djelomično otvara i tu temu, ostvarila i Iva Grgić 2003: 73-84. Autoričina analiza koja temu diskurzivnoga tretmana vrline (a u sklopu toga i djevičanstva kao vrline) u Marulićevoj Instituciji otvara iz feminističke perspektive vidi se usto snažnim poticajem ovome članku u kojemu će se djevičanstvo sagledati u drugačijemu analitičkom kontekstu, koji je ciljano, dakle, usmjeren prema problematizaciji kršćanske religijske konceptualizacije djevičanstva.

${ }^{9}$ U tom smislu pojam "kritička praksa" pored njegova općenita i šira značenja posebno upotrebljavam u onome smislu u kojemu taj pojam proizlazi iz definicije feminističke kritike kao analitičke aktivnosti koja se, kako predlažu Lada Čale-Feldman i Ana Tomljenović u Uvodu u feminističku književnu kritiku, može opisati na sljedeći način: "Feministička kritika nije naime tek još jedna metoda, tek novi krug interesnih fokusa ili problemskih čvorišta: ona radikalno preispituje same epistemološke, ontološke i sociokulturne pretpostavke subjekta (ne)znanja" (2012: 11). S druge strane, kako sugeriraju iste autorice, pojam "kritika" sadrži i "stav koji neumorno preispituje usvojene ideje, ali i svijest o osporivim granicama vlastitih spoznaja, uza sav aktivistički zanos prema promjeni svijeta, zanos iz kojega je feminizam iznikao, kao jednako politički koliko i intelektualni pokret" (isto). 
II.

Medievistkinja Salih Sarah u studiji Versions of Virginity in Late Medieval England predlaže ovakvu problematizaciju kršćanskoga koncepta djevičanstva: citirajući poznato Augustinovo objašnjenje "virgo nascitur etiam de stupro, sacra autem virgo nec de conjugio [djevica se rađa iz bluda, a sveta djevica čak niti iz braka]" (De s. virg. 401), Salih kazuje kako je religijski diskurs djevičanstvo uspostavio kao rodni identitet par excellence. Ono što je u teološkim opisima objašnjavano kao djevičanstvo, nije bilo neko dato i statično stanje, već se prije odnosilo na proces koji se u određenome vremenu odvija kroz ponavljanje određenih radnji, činova i aktivnosti koji nisu odjeljivi od određenih regulacijskih normi i praksi. Odnosno, kako sažeto formulira Salih (via Judith Butler), "[djevičanstvo je] rodni identitet konstituiran kroz kulturno značajne radnje" (usp. Salih 2001: 1-2). ${ }^{10}$

Na što valja obratiti pažnju u toj (re)definiciji djevičanstva? S jedne strane, na izbor metode: (re)definicija djevičanstva koju donosi Salih bez jasnoga razgraničenja udružuje ishodišnu religijsku predodžbu s kritičkim strategijama suvremene teorije. Takav postupak prevladava i u drugim analizama gdje govoriti o djevičanstvu kao o određenome povijesnom iskustvu isto tako pretpostavlja način gledanja koji je suvremen i koji uključuje suvremenu teorijsku shematiku i isto takve analitičke pojmove. ${ }^{11} \mathrm{~S}$ druge strane, na cilj takve analize: povezujući pojmove poput konstruiranosti (performativnosti) roda s tradicionalnim shvaćanjima djevičanstva (i u skladu s time, roda, spola i seksualnosti), ta proučavanja žele kako u postavljanju predmeta analize tako i u njezinim konsekvencama ostaviti otvorene mogućnosti za razmišljanja o pitanjima povijesnosti roda (i spola i seksualnosti), o tome kako se ti fenomeni oblikuju, pod kojim uvjetima i u kojemu kontekstu, te na koji način taj kontekst koincidira ili ne koincidira sa suvremenim. Uz to se nadalje vezuje i odabir teme: tri osnovne teme, kako ćemo nadalje vidjeti, prevladavaju u tim proučavanjima: rodna afilijacija religijskoga djevičanstva, njegova feminizacija te virilizacija. Sva su ta tri elementa (cilj, metoda i tema) međusobno povezana i svaki traži detaljnije objašnjenje; također, njihova povezanost detaljnije određuje i ustrojstvo ove analize.

Krene li se od teme, ponajprije valja istaknuti da iako je djevičanstvo u kršćanskome shvaćanju oblik asketske prakse koji je namijenjen kako muškarcima tako i ženama, svejedno ono ima naglašenu rodnu afilijaciju te se gotovo isključivo vezuje uz asketske žene. Naime, i dok je asketskim muškarcima djevičanstvo moglo omogućiti usavršavanje njihovih urođenih sposobnosti za posvećivanje načinu života koji pretpostavlja usredotočenost na moralni i duhovni razvoj pojedinca, ono nije bilo neophodno za uspostavu

\footnotetext{
${ }^{10}$ Naime, upravo je utjecaj teorije performativnosti roda Judith Butler, uz trajnu prisutnost Foucaultove analitike seksualnosti, a osobito njegovih proučavanja klasične i kršćanske askeze, sastavni dio tih analiza. U tom smislu vidi raspravu o uključivanju butlerijanskih koncepta u analizu srednjovjekovne i ranije kršćanske građe koju donosi Salih 2000: 31-42. Isto tako vidi i rasprave o Foucaultovu tumačenju asketskih praksi u kršćanskoj kasnoj antici i o njegovu utjecaju na kasnija historiografska proučavanja koje donose Clark 1986: 619-41; Lochrie 1997: 3-16; Boyarin i Castelli 2001: 357-75.

${ }^{11}$ Usp. Kelly 2000: 40-62; Salih, Bernau i Evans 2003: 1-14; Bernau 2002: 36-49; 2006: 105-122.
} 
njihova religijskoga identiteta kao što je to bilo ženama. Stoga se i tvorci različitih praktičnih tekstova od najranijega patrističkog doba pa nadalje uglavnom obraćaju ženama, koje je trebalo poučiti prikladnome ponašanju i oblicima dozvoljenih i nedozvoljenih oblika asketskoga života, ${ }^{12}$ mada to opet ne podrazumijeva da se i muškarce ne opominje na strogost asketskoga režima. Svejedno, kako primjećuje Kathleen Coyne Kelly u Performing Virginity and Testing Chastity in the Middle Ages:

Većina je patrističkih pisaca poput Tertulijana, Ambrozija, Jeronima i Augustina vrlo jasno isticala žensko djevičanstvo kao predmet kojim se bave. Mada ti autori djevičanstvo nastoje predstaviti kao idealno stanje i za muškarce i žene, oni se uglavnom ili izravno obraćaju ženama ili muškarcima pišu o ženama. (2000: 33)

Postoji, međutim, još jedan trenutak koji se često javlja u takvim tekstovima u kojim je djevičanstvo određeno kao specifičan način života što djevicu oslobađa od zadaća koje su ženi po grijehu i po Padu namijenjene: seksualnosti, braka i potomstva (Post 3).14 Raspravljajući o tome, Salih u spomenutoj studiji Versions of Virginity in Late Medieval England postavlja sljedeće pitanje: "Ako je žena određena Evinim prokletstvom, jesu li onda djevice, koje su podjednako lišene heteroseksualnosti i reprodukcije, neophodno uključene u kategoriju 'žena'?" (Salih 2001: 1). A da bi to pitanje bilo jasnije, valja podcrtati da je djevičanstvo u shvaćanju ranokršćanskih pisaca podrazumijevalo jedan vid osobitoga i strogo hijerarhijskoga odnosa između "žene" i "djevice”. Taj je odnos podrazumijevao i da se usavršavanjem u vrlini žena mijenja i to tako da njezin duhovni razvoj podrazumijeva progresivno kretanje od ženskosti prema muškosti. Takva je razlika između ženskosti i muškosti bila u uskome odnosu s uobičajenim parovima zapadnoga dihotomijskog mišljenja: tijelom i duhom/dušom, strašću i razumom, pasivnošću i aktivnošću i dr., a otuda i dolazi tema ženske asketske virilnosti kakva je bila općeprihvaćena u patrističkim raspravama o djevičanstvu, kao i u ranoj hagiografskoj literaturi koja donosi, već spomenutu, tipsku figuru virilne djevice (virago, femina virilis). ${ }^{15}$

S obzirom na to, suvremena feministička analitika ističe nekoliko važnih implikacija toga pitanja. Ako je tako da je djevičanstvo u tumačenju ranokršćanskih pisaca koncipirano kao određena vrsta manjinskoga rodnog identiteta ili tzv. treći rod, onda je to također osiguravalo vid shvaćanja prema kojemu su djevice mogle konstituirati svoju rodnu poziciju drugačije negoli žene i muškarci (usp. Salih 2001: 98). To je značilo da su "djevice” na taj način mogle biti shvaćane kao žene koje više nisu "žene", odnosno kao žene koje su mogle "postati

${ }^{12}$ Iz obimne patrističke literature obično se izdvajaju sljedeće rasprave: Ambrozije De virg.; De virgin.; Exh. virg.; Jeronim Ep. XXII. ad. Eust.; Ep. CVII. Ad Laetam.; Grgur iz Nise De virg.; Zlatousti De virg. O djevičanstvu u patrističkim teorijskim i praktičnim spisima, vidi osobito analize povjesničarki ranoga kršćanstva: Burrus 1995: 25-46; Castelli 1986: 61-88; Clark 1983; 1989; 1994; Cloke 1995: 35-46; Cox Miller 1993: 21-45.

13 To međutim ne umanjuje važnost muškoga religijskoga djevičanstva. O tome vidi više u Kelly 2000: 91-102; Riches 2002: 65-86; Lewis 2002: 87-102.

${ }^{14}$ Posebno vidi sljedeće rasprave patrističkih pisaca: Ambrozije De virgin. 1. 6.; Exh. virg. 9-14; Jeronim Ep. XXII. ad. Eust; Zlatousti De virg. 64.

${ }^{15}$ O asketskoj ženskoj virilnosti vidi i sljedeće priloge: Castelli 1986: 61-88; 1991: 29-49; Newman 1995: 22-45; Cloke 1995: 131-134; Salih 2001: 9-15. 
muškarci", ali to je isto tako podrazumijevalo i da svaka žena nije mogla postati "djevica". Stoga se Salih, s drugim feminističkim povjesničarkama, pita može li se u skladu s time djevičanstvo (re)definirati kao određena identifikacijska praksa koja sadržava mogućnosti da djevice, ustanovljavajući drugačiju rodnu kategoriju negoli onu koja je ženska ili muška, izazivaju "određenu nelagodu" unutar dvojno strukturiranoga rodnog režima (isto: 106). ${ }^{16}$ Ako pritom tome "zavodljivome anakronizmu" (isto: 243), kojemu je feministička analitika toliko sklona, opravdanje pronađemo u tome da postavljajući takva pitanja, u prošlosti ne tražimo "odgovore" ili "rješenja” koja bismo mogli dobiti, već okvir unutar kojega se mogu promatrati i neki od tekućih problema. $U$ tom se smislu stoga ističe kako je djevičanstvo pozicija s koje se može dobro sagledati konstruiranost roda kao takva: jer, iako je u religijskim terminima koncipirano tako da zapravo dosljedno potvrđuje inferiornost "žene" u odnosu na "djevicu" (u simboličkome smislu: "muškarca"), djevičanstvo svejedno dovodi u pitanje stabilnost kategorije "žena" (usp. isto: 242-43). To, opet, ne znači da je takva konceptualizacija djevičanstva donijela samo određenu reinterpretaciju hegemonijskoga rodnog poretka niti da ga je, opet, suštinski promijenila, ali to može podrazumijevati da je "barem na trenutak", kako primjećuje povjesničarka Elizabeth A. Castelli, bitno dovela u pitanje "prirodnu" nepromjenjivost odnosa među rodovima kakva dominira zapadnom tradicijom (1991: 33). ${ }^{17}$

S toga gledišta, i bez obzira na moguću predvidljivost zaključka, pristupam nadalje analizi Marulićevih tekstova. Ta predvidljivost je načelno dvojake prirode: s jedne strane proizlazi iz odabira upravo opisane analitičke perspektive i njezinih interpretativnih implikacija, s druge strane, Marulić je općenito, kako je znano, kršćanski pisac kod kojega je razmišljanje o moralu način da se interpretiraju, obnove i ponovo potvrde neke temeljne kršćanske vrijednosti i u tome je smislu “novina” koju uvodi u svoje tekstove uvelike u vezi s tradicionalnim etičkim pitanjima i praksama. Zbog toga, analiza ispunjenje i ne može imati u pukome potvrđivanju nekih općenitih saznanja, načela i pojmova, već teži razabiranju i razumijevanju načina kojima se takva jedna složena i imanentno proturječna konstrukcija kao što je djevičanstvo u Marulićevim tekstovima uspostavljala iznova obnavljajući svoja ishodišna utemeljenja.

III.

O djevičanstvu Marulić sustavno razlaže u V. knjizi Evanđelistara. ${ }^{18}$ Jezgru razlaganja čini njegovo nastojanje da novozavjetno učenje što jasnije objasni ne pokazujući prijeku brigu da

${ }^{16}$ Usp. Kelly 2000: 40-62; Salih, Bernau i Evans 2003: 1-14; Bernau 2002: 36-49; 2006: 105-122. Vidi i sljedeće rasprave Robertson 1990: 32- 40; Mclnerney Burnett 2003: 9-10.

${ }^{17}$ Vidi i feministička čitanja ženskoga asketizma koja donose Castelli 1986: 61-88; Clark 1994: 155-184; Cloke 1995: 134-35; Cooper 1996: 145-47, kao i Elm 1994; Burrus 1995: 25-46; Boyarin 1999: 195-217. Tkđ. vidi i jednu od najnovijih rasprava na temu feminističkoga teorijskog i analitičkog pristupa fenomenu ranoga kršćanskog ženskog asketizma koju isto tako donosi Castelli 2017: 271-282.

${ }^{18}$ lako Marulić u Evanđelistaru djevičanstvu posvećuje samo jedno tematsko poglavlje (Ev II, V: II), o tome raspravlja i u drugim poglavljima (npr. Ev I, III: 24; Ev II, V: 4; Ev II, V: XI). Na isti način postupa i u Instituciji, gdje se djevičanstvo odjelito obrađuje u: In II, IV: VII, VIII. 
praktičnu pouku nadopuni teorijskim pojašnjenjima. No zato iz njegova praktičnog razmišljanja nipošto ne izostaju teorijski konstruirane pretpostavke koje su o tome predmetu izricali patristički komentatori Pavlove Prve poslanice Korinćanima. Prema patrističkoj interpretaciji Pavlovih riječi o neophodnosti tjelesne i duhovne čistoće ("I žena neudana i djevica brine se za Gospodnje, da bude sveta i tijelom i duhom, a udana se brine za svjetovno, kako da ugodi mužu" [1 Kor 7, 34]), djevičanstvo je prije svega stanje volje (ili duha ili duše), a ne određeno stanje tijela. Tako u raspravi De virginitate Ivan Zlatousti objašnjava da djevičanstvo zahtijeva ispravnu i potpunu posvećenost koja se ne može svesti na skrbljenje o tijelu jer, kako kazuje, "nije dovoljno biti neudanom, da bi se bilo djevicom" (De virg. 77). Srodno objašnjenje donosi i njegov latinski suvremenik Jeronim, odgovarajući na pitanje prave prirode djevičanstva. "Evo definicije djevice", kazuje, " sveta u tijelu i u duhu; pošto ne bi bilo ništa od koristi imati djevičansko tijelo, ako nam se vjenčaju u duhu" (Ad. Helv. 20). A preko takva općeprihvaćenoga shvaćanja prirode djevičanstva, Ambrozije će posve jasno uspostaviti potpunu odvojivost duha od tijela, iz koje slijedi i da se djevicom može nazivati i ona žena čije je fizičko djevičanstvo narušeno, ali je "duh djevičanstva" ostao sačuvan (De virgin. 2, 4). ${ }^{19}$ Svejedno, takvo shvaćanje ne vodi nužno do činjenice pukoga omalovažavanja tijela. Naprotiv, kako će naglasiti povjesničarka Elizabeth A. Clark u utjecajnoj studiji Reading Renunciation: Asceticism and Scripture in Early Christianity, ortodoksnim kršćanskim piscima, čak i onima koji poput Marulića, kao što ćemo vidjeti, potiču razne forme trapljenja tijela, nikad asketizam nije bio primarno dualistički fenomen koji je tijelo i dušu shvaćao kao dvije ontološki različite stvarnosti niti su ti kršćanski pisci, uvijek svjesni opasnosti od približavanja dualističkim gnozama, ljudsko tijelo ("hram Duha Svetoga" [1 Kor 6, 19]) smatrali po sebi zlim, ma koliko ono u čovjekovoj podložnosti prema "moćima puti" (Rim 7, 22: 24) koje su u njegovim "udovima" (Rim 7: 22: 24) bilo otvoreno prema grijesima. ${ }^{20}$ Umjesto toga, podrazumijevajući neraskidivu vezu između tijela i duha (ili duše) živoga subjekta, radije ustraju na njihovu uzajamnom djelovanju, ne uzimajući sa sigurnošću ni da je duhom ili dušom lakše upravljati negoli tijelom. Stoga, kako opaža Michel Foucault u Povijesti seksualnosti 2,

Jedna od karakterističnih crta kršćanskoga iskustva "puti", zatim i "seksualnosti" bit će ta da je subjekt u njemu često pozvan sumnjati i iz velike udaljenosti prepoznavati očitovanja mukle i opasne sile koju je tim više potrebno odgonetavati jer je sposobna pritajiti se u mnogo drugih oblika, a ne samo u seksualnim činovima. (2013: 45)

A u skladu s time, seksualna aktivnost kao predmet moralnoga proučavanja neće u kršćanstvu ni biti toliko usmjerena prema samim žudnjama i zadovoljstvima, već prema razvoju posebnoga vida "odnosa prema sebi koji sadrži točne forme pažnje, sumnje, odgonetavanja, verbalizacije, priznanja, samooptuživanja, borbe protiv iskušenja, odricanja, duhovne borbe, itd." (isto: 67). Upravo u tom smislu vrijedi i shvaćati definicije prema kojima djevičanstvo nije nešto što se može ostvariti samo "sitnim nadziranjem tijela" (De virg.

\footnotetext{
${ }^{19}$ Detaljniju razradu vidi u Cloke 1995: 34-37; Kelly 2000: 1-14.

${ }^{20}$ O Marulićevu odnosu prema dualističkoj misli detaljno piše Jozić 2009: 239-247.
} 
18), već stalnim radom na "čistoći srca" (De virg. 5), kako nalazimo kod Grgura iz Nise. Ili, kako o istome piše Ivan Zlatousti u De virginitate, djevičanstvo ne zahtijeva tek "odsutnost grješnih i sramotnih želja, odsutnost suvišnih i prekomjernih briga, nego i neuznemirenost onim svakodnevnim brigama [što bi odvlačile dušu od potpune posvećenosti Bogu]" (De virg. 77).

Te iste teme, opet, susrećemo i kod Marulića, dok u X. poglavlju I. knjige Institucije, obrazlažući neophodnost stalnoga bdijenja nad samim sobom, ističe:

Djevičanstvo se kreće među tolikim opasnostima da ga i budne rijetko mogu sačuvati neoskvrnutim, a pospane nikad. Vi dakle, bilo djevice, bilo udovice koje ste da ste, ako u vas ima ljubavi za ćudoredan i svet život i ako ste se odlučile sačuvati čistoću duše i tijela, prihvatite se već zdušno toga posla, to jest bdijenja, ako želite polučiti odgovarajuću plaću od Boga. (In I, I: X [str. 155-56])

U tomu ulomku također i prepoznajemo Jeronima i odjeke njegova poznatog pisma djevici Eustahiji u kojemu se pojavljuje ista potreba da se upozori na osobitu zahtjevnost djevičanstva. Imajući na umu Matejevo: "A ja vam kažem: 'Tko god s požudom pogleda ženu, već je s njome učinio preljub u srcu'” (Mt 5, 28), Jeronim podučava da se djevičanstvo mora strukturirati u znaku potpune budnosti nad samim sobom jer se ono može izgubiti ne samo nekom pogrešnom aktivnošću ili oblikom ponašanja nego "čak i mišlju” (Ep. XXII. ad. Eust. 22: 5).

$\mathrm{U}$ istome tom znaku zaokupljenosti potrebom da se djevičanstvo što preciznije objasni u svojoj složenosti, Marulić pristupa i u Evanđelistaru, kojemu se sad naposljetku vraćamo. Ondje prije svega kazuje da je djevičanstvo idealan oblik kršćanskoga savršenstva koji valja shvaćati u odnosu s njegovom neposrednom povezanošću s onostranim: "Jer biti djevicom nadilazi prirodu i uobičajen život. To je prije nešto anđeosko negoli ljudsko" (Ev II, V: II [str. 112]). ${ }^{21}$ Međutim, iako djevičanstvo donosi iznimne nagrade na nebesima, također zahtijeva i posebne napore jer se čuvanje djevičanstva, obrazlaže, neprestano odvija u vidu borbe sa samim sobom, sa svladavanjem vlastite slabosti prema izazovima puti (Ev. II, V: II [str. 112]). U takvu opisu, u kojem se neprekidno naglašava postojanje neke moguće opasnosti, opet susrećemo Jeronima, stalnoga Marulićeva učitelja, koji će rado isticati da je "djevičanstvo težak zadatak i zato što je težak rijedak" (Adv. Jov. I: 36). U istome pismu Eustahiji, koje će dugo vremena kružiti i kao posebna knjiga pod naslovom De virginitate, a takvo ga poznaje i Marulić, Jeronim će mladu djevicu upućivati kako je pogrešno vjerovati da je djevičanstvo, unatoč odluci da "nema spol" (Ep. XXII. ad. Eust. 22: 18), tj. da ne zna za tjelesnu strast, oslobođeno "zasjeda" (Ep. XXII. ad. Eust. 22: 29) u koje dospijevamo zbog unutrašnje "vatre pohote" (Ep. XXII. ad. Eust. 22: 7) koju svi nosimo u svojim tijelima. "Doklegod zadržava nas ovo mlohavo tijelo", kazuje, "doklegod nosimo ovo blago u zemljanim sudovima i duh želi protiv tijela, a tijelo protivu duha, pobjeda nije istinita" (Ep. XXII. ad. Eust. 22: 4). Tu misao potanko razvija i Marulić kad u istome V. poglavlju II. knjige

${ }^{21}$ Prema Parlovu 2005: 303, Marulić tu referira na spis Epistola IX. Ad Paulam et Eustochium. De assumptione beatae Mariae Virginis, koji se obično pripisuje Jeronimu. 
Evanđelistara kazuje kako "nijedna strast kod živih bića nije žešća niti je teže savladiva" od "zlih želja" koje dolaze od tijela (Ev II, V: II [str. 112 ]). Tijelo je za njega "buntovno" (Ev II, V: V [str. 122 ]), lako podložno "moćima puti” (Rim 7, 22-24), te je on, u čijim se spisima može pronaći upravo jeronimovska zgroženost razornom snagom požude, duboko bio uvjeren da se ta "vatra" (Ep. XXII. ad. Eust. 22: 7) ne može ugasiti nikako drugačije negoli strogom asketskom disciplinom, stalnom borbom protiv "neposlušnoga" tijela. Urediti svoj život, kazuje tako, znači naučiti kako "pobijediti samog sebe" i kako "zapovijedati strastima koje se bore protiv razuma" (Ev I, l: 14 [str. 95-100]) te kako u tome biti nepokolebljiv i nadasve oprezan: “Jer da bi uvijek pobjeđivao, uvijek se boj da ćeš biti pobijeđen!” (Ev II, IV: VII [str. 48]). U njegovu opisu uzdržavanja stoga se više od svega nalazi jedan naglašeno "antagonistički odnos sa samim sobom" (Foucault 2013: 71) koji duhovnu borbu smješta u okrilje borbe s "unutrašnjim neprijateljem" (Ev II, IV: VII [str. 46]). ${ }^{22}$ Takav odnos također podrazumijeva i jedan aktivan i virilan stav prema sebi kojim se pojedinac dovodi u stanje čestitosti. To jest, "mušku” čvrstinu koja se vezuje uz pojedinca koji se odlikuje hrabrošću, jačinom i ustrajnošću duha, dakle vrlinama koje se od klasične antike pa nadalje smatraju tipično muškima. Također, za takav je oblik odnosa prema sebi od velike važnosti i to da se uzdržavanje odnosi na osobitu vrstu slobode koja se vezuje uz mogućnost unapređivanja samoga sebe $u$ odnosu s božanskom instancom. Kako objašnjava Clark u svojim proučavanjima kršćanskoga asketizma:

Unatoč očitim načinima kojima se asketizam u svojemu odjeljivanju od "svijeta" pokazuje pesimističnim pokretom, postoji određeni optimizam u njegovu središtu. Muškarci i žene nisu robovi ustaljenih svakidašnjih obrazaca, već se mogu ostvarivati iznimnim oblicima ljudske egzistencije. (1999: 17)

Asketski je život, u skladu s time, bio iznimna forma života; neka vrsta "samonametnutoga ograničenja" (Clark 2004: 48) koje se poimalo kao sloboda, kao iznimna prilika da se pojedinac unaprijedi i preobrazi “u čistu posudu božanske volje” (Elm 1994: 14).

Sve je to ranije već spomenuto i sve to predstavlja osnovne tematske sastavnice kompleksa ženske virilnosti i poznatoga toposa "postajanja muškarcem" koji je prevladavao i u hagiografskome korpusu iz kojega Marulić u Instituciji crpi građu za ženske primjere. Asketskim čitateljicama (djevicama i udovicama) pokazuje da je vladanje samim sobom odlika jaka i postojana, razborita duha koji je svojstven svetim ženama. U VII. poglavlju V. knjige O tome na koji se način valja othrvati napastima đavla tako pripovijeda o egipatskoj redovnici Sari, kojoj "običavao je đavao u svojoj zlohotnosti nametati misli kojima je u njoj pobuđivao tjelesnu požudu. Ali ona se", naglašava Marulić, "nikada nije molila da ta napast odstupi od nje, naprotiv, molila se neka je stalno napada, samo neka ona uvijek bude pobjednicom" (In VII: V). O redovnici Sari saznajemo i da se sedam godina ustrajno borila s demonom požude koji ju je uzalud napadao, dok se u X. poglavlju III. knjige O kažnjavanju tijela bičevanjem ista sveta žena navodi kao savršeni primjer asketske samodiscipline:

${ }^{22}$ Usp. Ev I, II: VI; Ev I, II: XX; Ev I, III:XX; Ev I, II: XXI; In I, II: III; in II, II: VIII; in II, II: X; in II, IV: I. 
Premda je šezdeset godina stanovala u samostanu podignutu na obali rijeke, predstojnica djevicâ u Sketu SARA nije podnijela da bi kadgod poželjela pogledati kroz prozor na vodu kako blago teče mimo ni na milinu susjedne livade da ne bi, gledajući to, osjetila kakav užitak. Ne znam da li je nosila kostrijet ili se bičevala, ali bih se usudio utvrditi da se tolika uzdržljivost očiju teže može obdržavati negoli podnositi kostrijet i bičeve. Po njezinu se primjeru valja postojano boriti sa čuvstvima naših osjetila koja se ni na koji način ne mogu odvratiti od zabranjenih, a kamoli ispraznih prizora - ako se tijelo ne podvrgne naporima, a duh Bogu. (In II, III:X [p.146])

Taj nam primjer omogućuje da još jednom sagledamo onaj naglasak na tome da je za odražavanje mira koji je potreban u djevičanstvu važnije od izravnoga kontroliranja tijela nastojanje da se suzbije svaka potreba koja bi uopće mogla buditi bilo kakav osjećaj zadovoljstva. No isto tako, taj nam primjer redovnice Sare - koja je vjerojatno ista ona koja je zaslužila mjesto u poznatoj zbirci propovijedi pustinjskih otaca Apophthegmata Patrum, i navodno tvrdila: "Ja sam žena samo spolom, ali ne i duhom" (Alph. Sarah 4; PJ 10.73; citirano u Cloke 1995: 120) - pruža mogućnost i da još dublje promotrimo fenomen ženske asketske virilnosti. Kako primjećuje E. A. Castelli u članku “I Will Make Mary Male’: Pieties of the Body and Gender Transformation of Christian Women in Late Antiquity", u ranokršćanskome se kontekstu topos "postajanja muškarcem", osim u vezi s naslijeđenim etičkim kompleksom, bitnije zapravo oblikovao oko novozavjetne Pavlove objave o novome poretku svijeta ("Doista, koji ste god u Krista kršteni, Kristom se zaodjenuste. Nema više: Židov - Grk! Nema više: rob - slobodnjak! Nema više: muško - žensko! Svi ste vi Jedan u Kristu Isusu! [Gal 3, 28- 29]), koja je u interpretaciji ranokršćanskih pisaca shvaćena kao prilika da sada svi (i muškarci i žene) "postanu muškarci". "Činjenica da je muškost povezana sa spasenjem (dok je ženskost povezana s grijehom)", ističe pritom Castelli, "nije novina u odnosu na tradiciju, ali je nova bila ideja da žena može dospjeti do svetosti i spasenja 'postajući muško'” (1990: 30). Ta je ideja isto tako podrazumijevala da je napuštanje "ženskosti" stalni znak osobne transformacije žene koja se sprema za čestit život i u tom smislu takva transformacija postaje uvjet za djevičanstvo, za virilan i borben odnos prema sebi koji se u njemu očekuje. Takva će transformacija isto tako podrazumijevati i da je virilnost žene uvijek u izravnoj vezi s onim što je natprirodno, ali i da ostvarivanje te virilnosti kroz simboličko prekoračivanje granica temeljne suprotstavljenosti muškoga i ženskoga suštinski narušava prirodni poredak svijeta. Te su točke ujedno i najosjetljiviji dio teorijskih objašnjenja djevičanstva; one su tražile posebnu pažnju naročito usredotočenu na to kako se "djevičanstvo" određuje kao nešto što je više od "ženstva", nešto što "djevicu" čini oslobođenom i slobodnom od bivanja "ženom".

Kad se s toga gledišta pogled vrati na Marulićeve spise, razabire se kao prvo uvjerenje o ontološkoj i etičkoj drugotnosti "žene" u odnosu na "muškarca”, koje je općenito karakteristično za kršćansku tradiciju, a posebno naglašeno kod Jeronima, kojega Marulić i u tome učenju slijedi. ${ }^{23} \cup$ Evanđelistaru tako nije teško zamijetiti srednjovjekovnu monaško-klerikalnu mizoginu retoriku tipičnu za karakterizaciju “žene”; spis je uostalom

${ }^{23}$ O Jeronimovu odnosu prema ženama vidi Clark 1989: 25-46; Cox Miller 1993: 21-45. 
uglavnom namijenjen kleru. ${ }^{24}$ Kataloški se nižu atributi slabe ženske naravi: "žena" se vidi opasnom i naprasitom, povodljivom i zavodljivom; snažan je izvor napasti za svakoga muškarca, a posebno onoga u celibatu (usp. Ev I, III: XXII (str. 318); Ev I, III: XXV (str. 333)). Žarište je pažnje na snažnoj povezanosti seksualne žudnje i "slabe žene"; žena se stoga pojavljuje kao snažna teološka kratica za kršćanske sveze tijela, puti i grijeha. ${ }^{25} \mathrm{U}$ Instituciji se "žena" ponovo definira toposom "ženske slabosti”, koji se javlja u dvije nove, ali u tradiciji podjednako vobičajene situacije. ${ }^{26} \mathrm{~S}$ jedne strane, autorskim se komentarima hvale svete žene kojima "nije smetao njihov krhkiji spol” (In I, II: III [str. 187]) da bi postigle "iste zasluge pred Bogom kao muškarci i jednaku moć da čine čuda” (In I, II: III [str. 187]). Svete se žene uzdižu kao iznimke svojega spola, dok se hvali sposobnost kojom su nadvladale urođenu “žensku slabost". U tome se svakako može vidjeti želja da se asketske čitateljice ("djevice i udovice") ohrabre jer bi postignuća svetih žena i tim "običnim" ženama mogla pomoći da odnesu pobjedu. U IX. poglavlju I. knjige tako i čitamo: "Dometnimo i nekoliko primjera slabijeg spola da bi se vidjelo kako i žene imaju svoje predvodnice u zboru svetica, pa neka ih, zahvaljujući daru božanske milosti, ili samo požele slijediti ili neka to ujedno budu i kadre!” (In I, I: IX [str. 147]). S druge se strane topos “ženske slabosti” upotrebljava i kako bi se na krjepost potaknuli i asketski muškarci, koji bi se trebali postidjeti "jer su se [u tome] dali pobijediti i nadvladati od žena" (In II, IV: X [st. 289]). No vrlo se rijetko muškarce poučava primjerima žena jer se, kako čitamo, najbolje uči iz sličnih primjera. Tako u V. poglavlju X. knjige nalazimo ovo objašnjenje: "A sada, kao što su se muškarci od muškaraca, neka se tako i žene nauče od žena [...]”(In III, V: X [str. 188]), srodno donosi i I. poglavlje IV. knjige: "A sada, ako koga možda mrzi nasljedovati muškarce, izložimo ženama primjere žena!" (In II, IV: I [str. 156]), a iz toga slijedi da je podjela primjera "prema spolu" motivirana isključivo praktičnim i didaktičnim razlozima. Međutim, pitajući se o širim implikacijama takve podjele, Iva Grgić u članku “Muška, ženska vrlina u Marulićevoj ‘nstituciji” zaključuje:

S obzirom na to da se u Marulićevom etičkom sustavu moralni čin, osim što mora biti dobar po sebi, mora također biti usklađen sa svojom konačnom svrhom, vidimo da autor, ne razrađujući je dalje teološki, konstruira i koncentrira specifičnu, spolnu razliku i na području kršćanske etike. (2003: 83)

Tu se konstataciju može samo ponoviti i potvrditi, ali uz određenu specifikaciju i izvjesno pojašnjenje koje bi bilo u skladu s ranije rečenim o djevičanstvu i prirodi ženskoga asketizma. U tom ću se smislu usredotočiti na središnju proturječnost kršćanske konceptualizacije djevičanstva kao mogućnosti koja istovremeno narušava, ali i potvrđuje heteronormativnu raspodjelu rodnih karakteristika. Dakle, upravo na ono pitanje koje je već jasno istaknuto kao važno za feminističku interpretaciju kršćanske tradicije i koje se najjednostavnije može sagledati promotre li se razlike, ali i sličnosti koje se u autorskim komentarima uspostavljaju između suvremenih asketskih žena ("djevica i udovica") kojima je Institucija namijenjena

\footnotetext{
24 Detaljnije o srednjovjekovnoj klerikalnoj mizoginiji vidi u McNamara 1994: 3-29 i Bloch 1991.

${ }^{25}$ O srednjovjekovnoj mizoginoj misli u Marulićevu djelu vidi Parlov 2005: 293-312.

${ }^{26}$ Usp. analizu “ženske slabosti” kod Newman 1994: 22-28; Clark 1994: 155-184.
} 
i svetih žena iz prošlosti, njihovih učiteljica kreposti. Kao ilustracija može poslužiti primjer koji se odnosi se na istu onu redovnicu Saru. O Sari se piše i u VII. poglavlju V. knjige Institucije, O ustrajnosti u kreposnu življenju, u kojemu se donosi odsječak svetičina života. Isti je odsječak sastavni dio i l. poglavlja III. knjige O kažnjavanju tijela bičevanjem i ovdje je već citiran. Ništa nije neobično u tome ponavljanju jer Marulić često poseže za istim svetačkim životima u kojima nalazi sadržaje prigodne za lako uobličavanje u pouku. Pa tako dok se ranije uzdizala redovničina duhovna čvrstoća, sada se hvali ustrajnost njezina duha, uz komentar: "Te pohvalne, štoviše i nužno potrebne stalnosti nije nedostajalo ni svetim ženama, što ćemo pokazati na primjeru ponekih od njih, pa im nimalo ne pristaje ono što se zna reći: “žena je uvijek prevrtljiva i promjenljiva'” (In III, V: VIII [str. 160]).

Taj je komentar načelno srodan prethodnima koji razvijaju temu "ženske slabosti" i isključivo poznaju pretpostavku da ženska moralnost sadržava tri komponente: slobodu, natprirodnost i virilnost. Dinamika je njihova odnosa već znana i pretpostavlja da se žena u moralnosti ostvaruje samo kroz mušku dimenziju ljudskosti koja u tome doživljaju vrline podrazumijeva svladavanje što uzor ima u djevičanstvu i stalnoj čednosti. Nesumnjivo to onda znači i da žene koje se nisu odlučile za izbor asketskoga života zapravo nemaju mogućnost sudjelovanja u moralnosti; kao što to podrazumijeva i da unatoč tome što su kršćanski pisci oblikovali pojam djevičanstva uzdižući važnost duhovne kreposti, a posve potisnuvši tijelo, žena može biti moralni subjekt isključivo ako je isključena iz područja seksualnosti. Ali ako se na taj način i može dakle ustanoviti da se pohvalom iznimnih žena (svetica), koje u simboličkome smislu više i nisu “žene”, samo još više učvršćuje stereotipna slika žene koja se lako predaje strastima i zadovoljstvima što vode lošemu i grješnome djelovanju, onda se razlikom između "običnih” i “iznimnih” asketskih žena mogu naglasiti još neke druge važne karakteristike toga tipa konceptualizacije ženske vrline. U tom slučaju tu razliku više ne treba uobličavati u smislu razlike između "žene" i "djevice" koju uvijek valja shvatiti kao razliku "žene" i "počasnoga muškarca”, nego upravo polazeći od virilnosti i stupnjeva njezine ostvarenosti. Tako se u autorskim komentarima u Instituciji, baš kao i u ranije citiranome ulomku o neophodnosti bdijenja, snažno provlači potreba da se asketske čitateljice upoznaju s očekivanjima koja pred njih postavlja život u vrlini. Ta je potreba, kako smo vidjeli i u Evanđelistaru, bila osovljena oko stalnog nemira "jogunastoga tijela", tijela koje po općeprihvaćenu uvjerenju uvijek kao sinegdohu podrazumijeva žensko tijelo. Ta očita činjenica međutim nipošto nije zanemariva. Štoviše, ona usmjerava pažnju i na nešto drugo: na to da djevičanstvo traži neprestanu brigu upravo zbog toga što se njegova nestalnost utemeljuje na trajnoj povezanosti sa svim onim što je "žensko" i na kraju krajeva, "žena". Međutim, jednako tako, ta činjenica dovedena do svojih krajnjih konsekvenca i sagledana unutar konteksta kakav Institucija gradi podrazumijeva i da su jedino svete žene iz prošlosti mogle izbjeći te nužne proturječnosti koje porijeklo imaju u "ženskoj slabosti”; "običnim" asketskim ženama to ostaje tek kao prilika koja se možda može ostvariti. Stoga bi se temeljem svih tih oblika i načina predstavljanja sudjelovanja žene u moralnosti moglo ustvrditi da se kod Marulića zamjećuje očita prisutnost uvjerenja da se unutar kršćanskoga morala može govoriti o suštinskome jedinstvu vrline i o tome da su vrline tek konvencio- 
nalno vezane uz pojedini rod, ali i o tome da se vrlina ostvaruje samo preko virilne etičke strukture zahvaljujući kojoj su svi mogli dosegnuti stanje "savršene muškosti". A u toj vrsti prividne jednakosti, koja je svima omogućavala slobodu oblikovanja jednoga novog ("muškog") sepstva i u kojoj se granica između staroga i novoga uspostavljala na razlici između muškarca (spasenje) i žene (grijeh), samo su žene koje više nisu bile "žene" mogle sudjelovati u moralnosti. Na taj se način Marulićev diskurs o djevičanstvu pokazuje dijelom jedne tradicije čije je trajanje u vremenu bilo dugo, a proturječja složena i dalekosežna.

\section{NAVEDENA LITERATURA I IZVORI}

Allan, Johnatan, Cristina Santos i Adriana Spahr, ur. 2016. Virgin Envy. The Cultural (In)significance of the Hymen. Regina: University of Regina Press.

Ambrozije. De Virginibus. = "O djevicama". U Sveti Ambrozije. 2001. Spisi o djevičanstvu. Split: Symposion, 15-89. - De virgin.

Ambrozije. De Virginitate. = "O djevičanstvu". U Sveti Ambrozije. 2001. Spisi o djevičanstvu. Split: Symposion, 91-155.- De virg.

Ambrozije. Exhortatio virginitatis. = "Nagovori o djevičanstvu". U Sveti Ambrozije. 2001. Spisi o djevičanstvu. Split: Symposion, 203-248. - Exh. virg.

Banić-Pajnić, Erna, 1992. “Problem 'humanizma’ humanizma”. Prilozi 35-36: 7-26.

Bernau, Anke, Ruth Evans i Sarah Salih, ur. 2003. Medieval Virginities. Cardiff: University of Wales Press.

Bernau, Anke. 2002. "Virginal Effect. Text and Identity in Ancrene Wisse". U Gender and Holiness. Men, Women, and Saints in Late Medieval Europe. Samantha Riches i Sarah Salih, ur. London: Routledge, 36-49.

Bernau, Anke. 2006. "Gender and Sexuality”. A Companion to Middle English Hagiography. Sarah Salih, ur. Cambridge: D. S. Brewer, 104-22.

Biblija. 2018. Zagreb: Kršćanska sadašnjost.

Bloch, R. Howard. 1991. Medieval Misogyny and the Invention of Western Romantic Love. Chicago: University of Chicago Press. https://doi.org/10.7208/chicago/9780226059907.001.0001

Boyarin, Daniel. 1999. "Virgins in Brothels. Gender and Religious Ecotypfication”. ELO5: 195-217. https:// doi.org/10.1086/492674

Boyarin, Daniel i Elizabeth Castelli. 2001. "Introduction. Foucault's The History of Sexuality. The Fourth Volume, or, A Field Left Fallow for Others to Till". Journal of the History of Sexuality 10/3-4: $357-$ 374. https://doi.org/10.1353/sex.2001.0048

Brown, Peter. 2008. The Body and Society. Men, Women and Sexual Renunciation in Early Christianity. New York: Columbia University Press.

Burrus, Virginia. 1995. "Reading Agnes. The Rhetoric of Gender in Ambrose and Prudentius". Journal of Early Christian Studies 3/1: 25-46. https://doi.org/10.1353/earl.0.0031

Castelli, Elizabeth A. 1986. “Virginity and its Meaning for Women's Sexuality in Early Christianity”. Journal of Feminist Studies in Religion 2/1: 61-88.

Castelli, Elizabeth A. 1991. "I Will Make Mary Male'. Pieties of the Body and Gender Transformation of Christian Women in Late Antiquity". U Body Guards. The Cultural Politics of Gender Ambiguity. Julia Epstein i Kristina Straub, ur. New York, London: Routledge, 29-49. 
Castelli, Elizabeth A. 2001. "Women, Gender, Religion. Troubling Categories and Transforming Knowledge". U Women, Gender, Religion. A Reader. Elizabeth A. Castelli, ur. New York: Palgrave, 3-29. https:// doi.org/10.1007/978-1-137-04830-1_1

Castelli, Elizabeth A. 2004. Martyrdom and Memory. Early Christian Culture Making. New York: Columbia University Press.

Castelli, Elizabeth A. 2017. "The Future of Sainthood". U Melania. Early Christianity through the Life of One Family. Catherine M. Chin i Caroline T. Schroeder, ur. Oakland, California: University of California Press, 271-282.

Chambers, Samuel i Terrell Carver. 2008. Judith Butler and Political Theory. Troubling Politics. London, New York: Routledge. https://doi.org/10.4324/9780203937440

Chin, Catherine M. i Caroline T. Schroeder, ur. 2017. Melania. Early Christianity through the Life of One Family. Oakland, California: University of California Press. https://doi.org/10.1525/california/9780520292086.001.0001

Clark, Elizabeth. 1983. Women in the Early Church. Collegeville, MN: The Liturgical Press.

Clark, Elizabeth. 1988. "Foucault, The Fathers, and Sex". Journal of the American Academy of Religion 56/4: 619-41. https://doi.org/10.1093/jaarel/LVI.4.619

Clark, Elizabeth. 1989. "Theory and Practice in Late Ancient Asceticism. Jerome, Chrysostom, and Augustine". Journal of Feminist Studies in Religion 5/2: 25-46.

Clark, Elizabeth. 1994. "Ideology, History and the Construction of 'Woman' in Late Antique Christianity". Journal of Early Christian Studies 2: 155-184. https://doi.org/10.1353/earl.0.0121

Clark, Elizabeth. 1999. Reading Renunciation. Asceticism and Scripture in Early Christianity. Princeton: Princeton University Press. https://doi.org/10.1515/9781400823185

Cloke, Gillian. 1995. "This Female Man of God". Women and Spiritual Power in the Patristic Age, AD 350-450. London: Routledge. https://doi.org/10.4324/9780203422540

Cobb, Stephanie L. 2008. Dying to be Men. Gender and Language in Early Christian Martyr Texts. New York: Columbia University Press. https://doi.org/10.7312/cobb14498

Cooper, Kate. 1996. The Virgin and the Bride. Idealized Womanhood in Late Antiquity. Cambridge etc: Harvard University Press.

Cox Miller, Patricia. 1993. “The Blazing Body. Ascetic Desire in Jerome's Letter to Eustochium”. Journal of the Christian Studies 1/1: 21-45. https://doi.org/10.1353/earl.0.0133

Čale-Feldman, Lada i Ana Tomljenović. 2012. Uvod u feminističku književnu kritiku. Zagreb: Leykam International.

Elm, Susanna. 1994. "Virgins of God". The Making of Asceticism in Late Antiquity. Oxford: Clarendon Press.

Evans, Ruth. 2003. “Virginities”. U Medieval Women's Writing. Caroly Dinshaw i David Wallace, ur. Cambridge: Cambridge University Press, 21-39. https://doi.org/10.1017/CCOL052179188X.003

Evans, Ruth i Lesley Johnson.1994. Feminist Readings in Middle English Literature. New York: Routledge.

Filipović, Vladimir. 1983. "Osnovi etičko-filozofske orijentacije Marka Marulića". Prilozi za istraživanje hrvatske filozofske baštine 17/18: 3-22.

Foucault, Michel. 2013. Povijest seksualnosti, 2. Zagreb: Domino.

Grgur iz Nise. De virginitate. = Grgur iz Nise. 1982. O djevičanstvu. Split: Symposion. - De virg.

Grgić, Iva. 2003. “Muška vrlina, ženska vrlina u Marulićevoj 'Instituciji”'. Colloquia Maruliana 12: 73-84.

Jeronim. Epistula XXII. Ad Eustochium. = "Eustohiji (Ep. XXII)". U Sveti Jeronim. 1990. Izabrane poslanice. Split: Književni krug, 20-60 - Ep. XXII. ad. Eust. 
Jeronim. Adversus Helvidium. = Sveti Jeronim. 2006. O vječnome djevičanstvu Marijinu. Protiv Helvidija. Split: Symposion - Adv. Helv.

Jeronim. Adv. Jovinianum = Against Jovinianus. U Philip Schaff, ur. i Henry Wallace, prir. 2007. Jerome: Letters and Select Works. NPNF: Second Series 6. New York: Cosimo Classics, 346-387 - Adv. Jov.

Jozić, Branko. 2002. "Marulić i dualistička napast". Colloquia Maruliana 18: 239-47.

Jozić, Branko. 2009. “Marulićeva Judita kao miles Christi”. Colloquia Maruliana 15: 187-204.

Kelly, Kathleen Coyne. 2000. Performing Virginity and Testing Chastity in the Middle Ages. London: Routledge.

Kelly, Kathleen Coyne i Marina Leslie, ur. 1999. Menacing Virgins. Representing Virginity in the Middle Ages and Renaissance. Cranbury, Newark: University of Delaware Press.

Lewis, Katherine J. 2002. "Becoming a Virgin King. Richard II and Edward the Confessor". U Gender and Holiness. Men, Women, and Saints in Late Medieval Europe. Samantha Riches i Sarah Salih, ur. 2002. London: Routledge, 87-101.

Lochrie, Karma. 1997. “Desiring Foucault”. Journal of Medieval and Early Modern Studies 27: 3-16.

Marulić, Marko. 1985. Evanđelistar I, II. Split: Književni krug. - Ev I; Ev II.

Marulić, Marko. 1986. Institucija I. Split: Književni krug. - In I.

Marulić, Marko. 1987. Institucija II, III. Split: Književni krug. - In II; In III.

Mclnerney Burnett, Maud. 2003. Eloquent Virgins. From Thecla to Joan of Arc. New York, Basingstoke: Palgrave Macmillan. https://doi.org/10.1007/978-1-137-06451-6

McNamara, Jo Ann. 1994. “The Herrenfrage. The Restructuring of the Gender System 1050-1150”. U Medieval Masculinities. Regarding Men in the Middle Ages. Clare A. Lees, Thelma S. Fenster i Jo Ann McNamara, ur. Minneapolis, London: University of Minnesota Press, 3-29.

Novaković, Darko. 1987. “Generički kontekst Marulićeve Institucije." U Marko Marulić. Institucija II. Split: Književni krug, 9-31.

Newman, Barbara. 1995. From Virile Woman to Womanchrist. Studies in Medieval Religion and Literature. Philadelphia: University of Pennsylvania Press. https://doi.org/10.9783/9780812200263

Parlov, Mladen. 1996. "Lik Krista patnika u djelima Marka Marulića”. Colloquia Maruliana 5: 57-85.

Parlov, Mladen. 2001. “Teme ‘Devotio moderne’ u misli Marka Marulića.” U Religijske teme u književnosti. Zbornik radova međunarodnog simpozija održanog u Zagrebu 9. prosinca 2000. Ivan Šestak, ur. Zagreb: FTI, 39-59.

Parlov, Mladen. 2005. “Lik žene u misli Marka Marulića”. Colloquia Maruliana 14: 293-312.

Parlov, Mladen. 2006. “Marulićeva Philosophia Christi”. Obnovljeni život 61: 289-305.

Posset, Franz. 2014. “The 'Rock'. Marcus Marulus Theological Patrimony Concerning the Interpretation of 'You are Peter and Upon this Rock I Will Build My Church'”. Colloquia Maruliana 23: 213-30.

Riches, Samantha. 2002. "St George as a Male Virgin Martyr". In Gender and Holiness. Men, Women, and Saints in Late Medieval Europe. Samantha Riches i Sarah Salih, ur. London: Routledge, 66-84.

Riches, Samantha i Sarah Salih, ur. 2002. Gender and Holiness. Men, Women, and Saints in Late Medieval Europe. London: Routledge.

Salih, Sarah. 2001. Versions of Virginity in Late Medieval England. Cambridge: D. S. Brewer.

Salisbury, Joyce. 1991. Church Fathers, Independent Virgins. London, New York: Verso.

Šimundža, Drago. 1985. "Opći pristup Marulićevu Evanđelistaru”. U Marko Marulić. Evanđelistar. Split: Književni krug, 13-40.

Šimundža, Drago 1986. “Teološka misao Marka Marulića”. U Marko Marulić. Pouke za čestiti život s primjerima. Zagreb: Globus, xvii-xxiv. 
Tomasović, Mirko. 1986. "Pisac svjetskog glasa”. U Marko Marulić. Pouke za čestiti život s primjerima.

Zagreb: Globus, xli-l.

Tomasović, Mirko. 1999. Marko Marulić Marul. Zagreb: Erasmus naklada.

Zlatar, Andrea. 2001. "Transformacije hagiografske matrice u Marulićevu djelu De institutione bene beateque vivendi per exempla sanctorum". Colloquia Maruliana 10: 77-85.

Zlatousti, Ivan. De Virginitate $=$ Chrysostom, John. 1983. On Virginity. Against Remarriage. Studies in Women and Religion 9. New York: Edwin Mellen Press - De virg.

\section{MARULIĆ'S DISCOURSE OF VIRGINITY IN DE INSTITUTIONE AND EUANGELISTARIUM}

Marulićs moral and theological work De institutione bene vivendi per exempla sanctorum (1506) is a collection of saints' lives and inspiring episodes from the Holy Scripture which have been narratively transformed into the literary form of an exemplum. Set out to provide spiritual edification by means of moral examples, De institutione particularly addresses ascetic female readers (virgins and widows). In doing so, Marulić's practical moral narrative does not develop a systematic conceptualisation of virginity, while in Euangelistarium (1516), a moral and theological work complementary to De institutione, virginity is elaborated upon extensively, mostly according to 1 Corinthians 7 and Jerome's exegesis on virginity. Based on these notions, this article focuses on the discourse of virginity in Marulićs writings. More specifically, the article examines Marulićs exemplification of female hagiography in De institutione with particular regard to the phenomenon of female ascetic virility which was characteristic for early types of female sanctity.

Keywords: Marko Marulić, De institutione bene vivendi per exempla sanctorum, Euangelistarium, hagiography, virginity studies 